\title{
Why is there stability in Dagestan but not in Chechnya?
}

\author{
Enver Kisriev
}

\section{The formulation of the question}

$\mathrm{D}$ AGESTAN, UNLIKE CHECHNYA has demonstrated enviable political stability. This Caucasian republic, unique in its multi-ethnic composition, ${ }^{1}$ undergoing radical changes and similarly experiencing serious social transformations, nevertheless successfully preserved its integrity; it did not allow mass inter-ethnic clashes, social disorder and uprisings, and refrained from border disputes with neighbours. Although there were instances of serious tension in the republic (the last military actions in the Botlikhskii and Tsumadinskii mountains were in August-September 1999 - the bloody conflicts with the 'independent Islamic territory' of the villages of Karamakha and Chabanmakha, and the conflict with the armed Chechen divisions, who penetrated into Novolakskii raion), the course of their development and their results bears witness to the fact that in Dagestani society there are mechanisms at work which have up until now helped prevent the worst.

Particularly striking in this respect is the contrast with the political fate of neighbouring Chechnya. The Republic of Chechnya borders on Dagestan. Chechnya and Dagestan are linked through many significant episodes of history, in particular the general struggle against Russian expansion in the nineteenth century and the formation of a single state, the Imamat of Shamil', who lead the Caucasus mountain peoples' struggle against Russian colonisation for twentyfive years. ${ }^{2}$

Meanwhile, recent history demonstrates completely different political conduct in Dagestan and Chechnya. In Chechnya there has been a national revolution and independence has been declared, but in Dagestan it has not been possible (for internal reasons) even to approve the sham 'Declaration of State Sovereignty', which all the national republics of the Russian Federation passed in 1991 under the direction of the Kremlin. Chechnya put up an unprecedented armed resistance to the Russian army in 1994-96, whereas Dagestan constantly devoted its energies to ever greater integration with Russia. 
How is this to be explained? Which historical, socio-cultural or political conditions and mechanisms secure the maintenance of internal stability in multiethnic Dagestani society but do not allow the single Chechen nationality ${ }^{3}$ to aim for the unity of their own political elite necessary for the founding of an independent state? Why does the multi-ethnic, continuously in-fighting Dagestani elite nevertheless arrange a system of effective cooperation among themselves and seek close collaboration with Moscow, but the Chechen leaders, who belong to one nationality, are at odds with one another in the periods of peaceful independent development and unite only in times of direct opposition to Russia, exhibiting a monolithic and effective unity in these instances? These are difficult questions and this is an attempt only partially to clarify the relevant issues. Most attention will be concentrated on the analysis of most recent political processes in Dagestan. In the course of the analysis we try to note the essential differences between Dagestan and Chechnya within the examined parameters of ethnocultural, historical and socio-political themes.

\section{The structure of the new elite}

The political and economic revolution which took place in the Soviet Union in the late 1980s and early 1990s may be called a 'revolution from above'. Quite clearly the famous existentialistic philosopher Karl Jaspers was not right when he formulated the idea that 'once introduced, a dictatorship cannot be removed from within' (Jaspers 1991: 218). Drawing on the experience of the political history of the first half of the twentieth century, he maintained that "everything that we know of the terroristic state with its characteristic total planning and bureaucracy bears witness to the fundamental impossibility of stopping this almost automatically self-preserving machine, which grinds up all internal resistance'. Indeed, a leadership totalitarian in character and without the control of society cannot be changed from below, but it has turned out that for this purpose external interference is not at all necessary; change in the political regime and all systems of social relations can take place from above, if the political and economic elite, having been gradually reconstituted, takes on this task. Radical changes in the political and economical structure of the state, effected by the ruling elite in correspondence with its new system of values, are possible precisely in a totalitarian political structure, in which there is no possibility of societal influence on the selection of political leaders and the taking of decisions of crucial importance for the country. That such a revolution took place in Dagestan is shown by the fact that radical transformations with catastrophic effects on most layers of society and especially on those who determine the character of the development of contemporary industrial society - i.e. qualified workers and technicians, highly qualified specialists (doctors, engineers, teachers, university lecturers, scientists, etc.) - practically did not affect the top layer 
of society (the political, economic and cultural elite of the country), which remained almost entirely as it was, 'on top'.

In the meantime, however conscious and purposeful this process, once embarked upon, it unavoidably called into being developments which the initiators of perestroika did not expect. Such is the nature of social process: it can never be completely assessed and controlled. New tendencies, developing unobserved in the social system, unexpectedly begin to reveal themselves and alter the future which the reformers would like to reach. Already after the 'glorious revolution' the social elite begins to undergo essential changes not only in the course of the natural succession of cadres, but also under the influence of deep-seated and unforeseen changes in society.

In Dagestan and in Chechnya these processes developed as in the rest of the country, but with essential, quite definite peculiarities conditioned by the difference of historical conditions and existing ethno-cultural specificities, which did not reveal themselves in any way within the framework of the totalitarian communist regime, but with its collapse burst out and began to build new political relations.

The general nature of the elite's structural changes in the new postCommunist society was that the main development was not the replacement of representatives of the 'old guard' by the leaders of a new formation, but the swelling of their number by the nouveaux riches, which Soviet society had not known. Previously, advancement 'upwards' as a rule proceeded by moderate steps under the strict control of high Party and state authorities. Special principles for the selection and positioning of cadres were consciously framed by a large number of formal requirements and procedures (for instance by the composition of a nomenklatura of responsible workers of different levels and the supervision of their advancement), which it was formally impossible to avoid. The sharp increase in the total number of state bureaucrats in the country speaks vividly of the fact that in the new conditions a unification of the old elite with the new took place. While it seemed that the fall of the giant Soviet communist regime should have lead to the simplification and rationalisation of the institutions of state governance, the opposite occurred: according to estimates, the total number of civil servants increased in Russia by 50 per cent, and in Dagestan by 100 per cent.

In Chechnya these processes developed differently, beginning with the fact that the political history of these two republics in the socialist system differed significantly. At the end of the 1920s in the North Caucasus the young Bolshevik regime, after putting down the uprising of the Imam Nazhmudin Gotsinskii and Sheikh Uzuna-Khadzhi Saltinskii in Dagestan (subsequently to be taken up by the inhabitants of Chechnya), proclaimed the formation of two 'autonomous' multi-ethnic republics: the Dagestani and the Gorskii Soviet Socialist Republics (SSR). 
For the first three years the political fates of these North Caucasus state formations appeared diametrically opposed: the Gorskii SSR began to collapse in the first year of its existence and by 1924 had ceased to exist, falling into eight administrative units: six national oblasts (Karachaevo-Cherkasskii, Adygeiskii, Kabardino-Balkarskii, Chechen, North-Ossetian and Ingush) and the two cities, Vladikavkaz and Groznyi, became independent administrative units with direct subordination to the recently formed krai of 'South-Eastern Russia' with its capital in Rostov-on-Don, part of the Russian Republic of the Soviet Union (RSFSR). Dagestan, in this same period, not only preserved its state status of 'autonomous national republic' but also almost doubled its territory at the expense of Caspian coastal flat lands to the North.

The further history of Chechen statehood is even more dramatic. In 1922 the Chechen okrug was separated from the Gorskii SSR and made into an autonomous oblast (AO) of the RSFSR. After the complete abolition of the Gorskii Republic in 1924, the Ingush AO was also founded. At the very beginning of 1934 both of these oblasts were unified into the Chechen-Ingush AO, which in three years, in December 1936, was finally made into a republic, the Chechen-Ingush Autonomous Soviet Socialist Republic (CIASSR). However, in February 1944 this Republic, under the order of Moscow, was abolished and the Chechen and Ingush peoples were one and all rounded up from their homes, loaded onto railway carriages and sent to remote regions beyond the Urals and in Central Asia. Only in 1957 was the CIASSR restored with the loss of the Prigorodnyi region, left in Ossetia, but the Chechens and Ingush permitted to return to their lands. Finally, in the autumn of 1991, after the fall of the communist regime, and in the course of opposition to the centre for independence, the Chechen-Ingush Republic painlessly and by mutual agreement once again fell apart into the Chechen (independent) and the Ingush ('autonomous', but part of Russia) Republics. In the course of this long period of Chechen and Ingush political formations, the political status of Dagestan did not change once.

The existing difference between Dagestan and Chechnya in the period of communist leadership was also that in Dagestan throughout the whole of its Republican status the highest leaders were, as a rule, representatives of the core nationalities. In the early years after the Revolution and in the period of pre-war economic development in Dagestan, the key posts were given to representatives of local peoples. Many of them had received high-class educations before the Revolution in the universities of St Petersburg, Moscow, and in Germany and France - the Dargin Alibek Takho-Godi; the Kumyk Dzhalalutdin Korkmasov; the Avar Magomed Khizroev; the Lezgin Nazhmudina Samurskii and others. Starting with the post-war period, the primary officials (First Secretaries of the Republican Committee of the Communist Party of the Soviet Union - CPSU) of Dagestan were exclusively Dagestanis. In 1948, after the departure of the Azerbaijani A. Aliev, who lead the republic throughout the Second World War, 
the Avar Abdurakhman Daniyalov was the head of the Republic until 1967; then the Dargin Magomed-Salam Umakhanov until 1983; the Avar Magomed Yusupov until 1990 and Mukhu Aliev right up to the liquidation of the CPSU in autumn 1991. Apart from this post, all three of the highest positions in the Republic (First Secretary of the CPSU, Representative to the Union of Ministers and Representative to the Upper Soviet) were always, from the post-war period onwards, occupied by ethnic Dagestanis. At the same time, these three posts were formed in such a way as to be always held by representatives of the three different nationalities. In the post-war period the following sequences in the changing 'troika' were arranged as follows: Avar - Lezgin - Dargin; Dargin - Kumyk Avar; Dargin - Avar - Kumyk; Avar - Kumyk - Dargin. The controlling presence of the Russians was manifested only in the institution of the 'second secretary' of the republican CPSU organisation and the post of the head of the KGB in Dagestan.

In Chechnya-Ingushetia the first time that the highest post in the Republic could be held by a 'national' was only in 1989, in the later phase of Gorbachev's perestroika. It was held by the Chechen Doku Zavgaev. At the same time, the First Secretary of the republican CPSU organisation received his post not from the hands of Moscow, as it had been always and everywhere, but contrary to the Central Committee's recommendation, in the course of internal conflicts in the republican CPSU organisation and on a wave of glasnost and 'democratisation'.

This aspect of Chechnya's political history, namely that the first Chechen came to power in the Republic only in the phase of breakdown in 'the leading and guiding power' and as one of its manifestations, is usually underestimated by analysts trying to understand the reasons for the 'Chechen phenomenon'. In Chechnya-Ingushetia the communist regime possessed qualities which it did not possess in Dagestan. In Dagestan the Russian component in the creative sphere (science, literature, art) did not have a meaning linked to the exercising of dominion power. Thus, for example, in Dagestan the most authoritative academics in historical studies were ethnic Dagestanis. At the same time, it stands to reason that there was no dominating concept of Dagestani history. After 1956, when the ten-year period of the, imposed from above, historical negative attitude towards the activity of Imam Shamil' ended, the theme of 'the national liberation movement against tsarism of Dagestan and Chechnya's mountain peoples under the leadership of Shamil" was one of the most researched and widely taught university courses in the Republic.

In Chechnya-Ingushetia in the last period of communist rule the Russian professor V. G. Vinogradov, who was hated by the local intelligentsia, held complete sway in historical studies and generally in the field of ideology. He was the chief ideologist of the republican CPSU organisation, in which the highest post was always occupied by a Russian. His absurd and cynical 'concept' of 'the peaceful and voluntary entry of Chechnya into the Russian Empire' was thrust upon 
society. He was the censor for all academic activity within the Republic and the chief selector of national cadres for the state-Party nomenklatura (Gakaev 1999: 150). Thus, right up until the very end of the communist regime's supremacy, Chechens experienced direct and tangible national-cultural oppression from the centre, which was absent in Dagestan.

It is notable that in Dagestan one of the famous historians Professor Vladilen Gadzhiev also adhered to the theory of the voluntary joining of Dagestan to Russia. He based his point of view on diplomatic documents, which were evidence of the numerous agreements of local Dagestani landowners with Tsarist powers. However, his position was never the only one and never predominated.

Therefore the coming to power of a Chechen in 1989 in ChechnyaIngushetia was a genuine revolution in the Republic's history, it was viewed by the national intelligentsia and people as a long-awaited liberation from Russian diktat and to a significant extent this event determined the character of future events, which so differ from how events developed in Dagestan.

In Dagestan in the course of perestroika no particular changes in the cadres of power took place. The CPSU was headed by an Avar, the government by a Kumyk and the so-called representative of (Soviet) power was a Dargin. These three people cooperating and clashing between themselves throughout the upheavals of the perestroika process maintained the Republic in a condition of relative calm. Not one of them could be 'extracted' from the system without all the remaining leaders undergoing precisely the same fate.

The first real threat to destabilise power in Dagestan came with the fall of the communist regime (August-September 1991). The Avars (numerically the largest people in Dagestan) as a result of the fall lost the 'highest' (although at that time already significantly dissipated in its influence) post - the leader of the republican CPSU organisation. After a few impressive 'people's demonstrations', which threatened mass inter-ethnic clashes, order was restored; and the former leader of the Republican Committee of the CPSU took the post of the first deputy to the Chairman of the Upper Soviet of Dagestan. The shaken parity of powers was in this way partially restored. Of course, hidden tendencies continued to develop and in the end, essentially transformed the structure of the political elite in Dagestan. To characterise this structure let us begin with the subdivision of the ruling elite in Dagestan in two groups:

- high-ranking officials and bureaucrats;

- authorities in the non-governmental sphere, large-scale entrepreneurs, leaders of social organisations and (or) informal groups, drawing on large financial resources and the mass support of their followers.

The relationship between these categories on the Dagestani Olympus could be thought of graphically as a partial overlapping of two large groups. Thus, the formation of another higher category of ruling elite ran parallel to the formation of 


\section{Stability in Dagestan but not in Chechnya?}

this 'binary' structure and within its framework. Speaking visually, this might be located in the area where the two original groups overlap. At the same time, the traditional situation was unavoidably preserved: groups of a few different nationalities, supported even more by the numerous national groups of the "second echelon', remained in power. The formation of this 'third' (higher) category of ruling elite was brought about by two opposing tendencies:

- the enrichment of high-ranking state bureaucrats, their (new to them) involvement in public political activity and the unavoidable formation around them of latent structures of armed support;

- the acquiring by 'charismatic' figures and nouveaux riches of high-ranking state or economic posts through the procedure of state appointments or democratic elections.

Both tendencies led through a zone of numerous, often extremely embittered conflict situations to the formation of a top political elite consisting partly of representatives of the old regime but mostly coming from the nouveaux riches of the perestroika epoch. In this way, the general structure of the ruling elite in Dagestan does not consist only of the two original categories, but also of a 'third'. It is very clear that the 'third category' of the ruling elite is made up of the most influential persons, relying on their national groups, and is gradually gaining influence and control and is becoming the dominant group. The numerous members of the two 'first' categories of elite, who have not succeeded in acquiring the qualities of the third category, have found themselves in many ways marginalised. They ended up on the fringes of the ruling class. It is well known that as a result of this divergence in status, members of marginal groups are more radicalised; however, while being divided into 'national quarters' and 'marginals', they were getting themselves involved in the difficult process of political bargaining, but they did not call upon the people to overthrow the existing power regime.

All this did not save Dagestani society from clashes of an extremely bitter character within the Dagestani ruling class: above all, between 'heavyweights', i.e. among the representatives of the 'third' category of elite, but also between the 'third' and the two original categories; between the two original categories; and finally, within these two original categories. In the course of these conflicts an interwoven network of horizontal and vertical relationships of power and subordination formed, the subjects of which were the ethnic monolithic groups. Although there was a tense stand-off between 'heavyweights', they were no less interested in agreeing on a common course of action against a member of the 'second rank'. The 'second-rank' fragments were in the course of internal feuding developing into groups of support for one or the other 'heavyweight'. Simultaneously, representatives of the 'second rank' ('marginals'), trying to get into the higher category or, at least to retain high-ranking offices or material resources, sought support either from 'above' or 'below', building hierarchical chains of patron-client relations. 
There were many excesses in Dagestan, but they all had a 'patchy' character, i.e. they did not get prolonged into mass demonstrations and clashes between large groups of people. According to data officially published in June 2001, after a series of attempts on the life of Magomed-Salikh Gusaev, the Minister for Nationalities, Information and External Relations, who is popular in Dagestan there have been eighty-six terrorist acts and other crimes were committed against representatives of power in Dagestan since 1990. From these, there were 160 killed and 300 injured (Novoe delo 22 June 2001). All of this did not affect the political stability in the republic of Dagestan in any way.

It was clear that the strongest basis for the formation of this interwoven network of relations between numerous authorities was a difference in nationality. The theme of the nationality of leaders and their groups in Dagestan burst into life and became crucial in political discourse for the duration of the transitional period, and remains so. At the same time the Russian component of the Republic's ruling class was completely insignificant.

In Chechnya, it all turned out completely differently. After 'their own' (Doku Zavgaev) came to power the euphoria of national celebrations quickly gave way to the prosaic humdrum of political struggle, for the victory passed to one person alone. The coming to power one of 'their own' in place of a 'Russian' did not bring, and nor could it have brought, a general national unity in the conditions of increasing destabilisation in the country and the previously invisible but now revealed possibilities for enrichment. A new stage of bitter fights for power began, but now among 'their own'.

Under the slogans of national unity and cleaning the authorities of corruption Dogu Zavgaev, like any new leader, began to strengthen his personal power. In this connection the highly characteristic action of the new highest Party leader was called the 'Spring Fall' among the people. In February-March 1990 in all the rural regions of the Republic there was a wave of meetings and demonstrations of people's protest demanding the dismissals of the raion CPSU First Secretaries. This time it was a question not of Russians, but of Chechens and Ingush. In one month, seven First Secretaries and the majority of responsible CPSU and soviet bureaucrats, workers and law enforcement agencies were dismissed, and most of them were of Chechen nationality. Everywhere Zavgaev was able to put his people in the vacated posts and only in one raion (AchkhoiMartanovskii) did the leader of a local informal movement (Sh. Gadaev) succeed in becoming leader (Muzaev and Todua 1992: 35-36).

Analysts assert that there is no doubt that the 'people's demonstrations' were organised by Zavgaev himself in order to strengthen his power. As the wellknown Chechen historian Dzhabrail Gakaev writes in his article cited above: 'the wave of meetings, which occurred in the rural regions of the CIASSR in February-March 1990 was initiated by Zavgaev with the help of the People's Front.' Furthermore Gakaev expresses the important idea: 'It did not remain 


\section{Stability in Dagestan but not in Chechnya?}

unnoticed that Zavgaev used the people's discontent and meetings in the regions for the dismissal from power of people in the rural regions of the Republic who were unwelcome. Soon, Zavgaev's political opponents employed just such a device against him' (Gakaev 1999: 153).

The device used by Zavgaev was also actively employed in Dagestan. However, there, where power is traditionally shared between representatives of the different nationalities of a multi-ethnic society, the consequences of such actions turned out completely differently. In Dagestan all actions linked to the substitution of leaders of the central team require agreement and adequate compensation in order to preserve the balance. In Chechnya, all actions which reinforced the leader of the Republic led to the reinforcement of discontent and to resistance on the other pole - in the irreconcilable opposition camp. This binary polarisation of all political forces (on the one hand those in power, and on the other the opposition to those in power) in a transitional and transforming society can easily 'swap poles' and as a result of this become even more unstable.

Soon, Zavgaev laid his hands on the duties of the Presidium of the Upper Council of the CIASSR, both preserving for himself the dying Party power and forming from his people the whole pyramid of power, which in Dagestan, owing to the reasons noted above, could not have been accomplished. In this way, in Dagestan we have revealed an elite, which one can divide into two, mutually intersecting categories: on one side high-ranking officials and state bureaucrats and on the other authorities in the sphere of non-governmental activities, etc. which, in the course of mutual opposition, forms a new higher stratum of groupings led by representatives of different nationalities which oppose, but also cooperate between, themselves. In Chechnya something completely different came about. Here, the two given, primary categories have begun to disperse to two different poles. Moreover, power turned out to be built as a pyramid, without tension and counterbalances. There was no room for any kind of separate and opposing groupings within the system of power.

It also proved to be important that both opposing forces in the struggle against each other appealed and sought support not in different segments of society, but in one target general to both - the Chechen people. This led to the 'echoing' of nationalist feelings. Those in power explained all their actions as being in the interests of the Chechen nation, which the opposition also did in the struggle against those in power. In every case the raising of nationalist feelings may be nourishing opposition forces from without, i.e. most often Russia.

However, the ethnic 'monolithic' character of the Chechens, which brought such an easy and painless 'divorce' from the Ingushetians, concealed, for the time being, the explosive force of traditional Chechen clan structures (teips) and other associations (see below). Zavgaev could not but use the force of cohesion within the clan in the course of reinforcing his personal power; already, then, 
internal teip solidarity had awoken to political life. Subsequently, it tore the whole of Chechen society apart.

\section{Nationality, dzhamaat and teip}

Dagestani nationalities, just like the Chechens, even in the recent past hardly existed. Imam Shamil' in his struggle against the Russians did not know of any nationalities in Dagestan and did not formulate any 'national' tasks. For him and his brothers-in-arms at that time the subjects of political confrontation were completely different. The political discourse of that time in Dagestan distinguished between 'orthodox Muslims' and 'those, who called themselves Muslims, but were not' as the central political opponents. Avar, Dargin, Kumyk, Lezgin, Lak, etc., 'Dagestani nationalities' from an ethnographic point of view, existed objectively far more clearly then than they do now, however at that time they were not meaningful elements of socio-political discourse, they did not contribute to social consciousness, they were not a means of ideological reflection on events taking place and the motivation of the actions of their participants.

Occasionally one can read in the text of the chronicle that someone "cried out in the language of Ansali' or that 'Shamil'" spoke to them through a translator', but a person's nationality - which has become for contemporary Dagestanis practically the most important attribute of a person's identity remained outside the field of vision of the enlightened person of that time.

At the same time, in the very same chronicles of the Caucasian wars, Chechens appeared for all the Dagestani chroniclers as something whole and different from 'Dagestanis'. It was stipulated that in Chechnya there were no politically differing compact territorial formations, analogous to the Dagestani 'unions of free societies' - or 'republics' as the Russian military correspondents called them - or authoritative 'principalities': shamkhalates, khanates, utsiinates, etc. But the clan structures of Chechens in the conditions of strict Shariat, and generally all mountain peoples, were established by Shamil' as an enemy in the face of the 'gyaurs' (unbelievers), and they were in this political context absolutely inseparable.

The development of different 'nationalities' - Avar, Dargin, Lezgins, Kumyks, Laks, Tabasaran, Nogay, Tats, Rutul, Aghul, Tsakhur but also Chechens and Ingush, took place first in the period of the communist regime. This process took place in a framework developed by the Bolsheviks, with the understanding of nation and people enforced by violence, and in the context of a national policy of 'the self-determination of peoples'. It is true that the understanding of 'national self-determination' was then emptied of any authentic political meaning, and instead was filled to the brim by a whole wealth of ethnographic material.

The contemporary nationalities of the mountain peoples developed 'from above', pre-empting a national consciousness, as a result of decisions taken by 
the authorities relating to the establishing of a 'scientifically founded' nomenklatura of nationalities and their registration in all civil documents, bureaucratic forms and passports. Of course, in doing this attention was paid to objective ethnographic characteristics and to ethnic identifications developing in the consciousness of the population. It must be said that signs of ethno-cultural proximity or ethnic relatedness did not necessarily constitute factors in determining the motivation of national self-identification. They may have proven to be the idea of political conjuncture, the communist leadership's changing political blows in the direction of 'ethnic processes' (the 'dawning' or 'rapprochement' of Soviet peoples) or, let us say, the nationality of high-ranking officials or other social, political and far from ethnographical factors.

The communist regime, propagating proletarian internationalism in this phase of its formation, in the following phase initially underwent unavoidable nationalist erosion precisely in the elite; to start with in the artistic elite, then carefully supported by the scientific and political elites. The history of the last twenty-five-thirty years of the USSR was marked by a growing social awareness of nationality. Because, as the regime decayed, personal relations of trust which, as is well known, are easier to establish among persons of a common ethnic origin, started to acquire more and more importance among the ruling class in the centre and the republics, and a hidden nationalism began to put down strong roots.

Similarly in Dagestan, with its particular multi-ethnic structure, monoethnic groupings of mutual dependence and support not perceivable on the surface of public life started to form, especially among the elite. The process of strengthening national bonds vertically and horizontally initially remained in the shadows, but immediately after the collapse of the communist regime in August 1991 the forces which had formed, based on intra-ethnic solidarity, revealed themselves in all fields of political struggle. The peculiarities of the Dagestani ethnic structure detailed above began under the new conditions to determine the direction of political process in Dagestan. The ruling elite of the Republic, consisting of representatives of the basic Dagestani nationalities, having lost their base in the power structures which had collapsed, re-established it in the systems of confidence between personal friends, relatives, co-regionalists and especially among co-ethnics.

The national organisations of the respective peoples, emerging and gaining strength and authority in the population, actively opposed the republican authorities, thus forcing the old ruling elite to strengthen vertical intra-national ties. This is why the subsequent political process in Dagestan consisted of the extension of the political elites' influence on the national movements of their peoples. High-ranking officials tried to become the leaders of their peoples, and the informal leaders of the national movements and the nouveaux riches, who stepped forward completely unexpectedly, endeavoured to become members of 
the ruling elite. To a certain extent both goals were realised. As a result, in the course of the transformation of the 1990s the multi-ethnic structure of Dagestan turned into a decisive political factor.

The mobilisation of political forces in the republic did not take place on the basis of ideological differences and political parties, but of identities, at the core of which were traditional ethno-cultural values. Nationalities, which quite recently still did not play any political role and were merely objects of the 'national politics' of an authoritarian and essentially centralised state, were now transformed into the determining subjects of the political process.

In Chechnya-Ingushetia ethnic processes ran differently. From the very beginning, Chechens and Ingush, as an integral unit, differed distinctly as independent peoples, and in their political history within the framework of the communist system. This was reflected in the administrative divisions of the 1920s, which were directed from above. Subsequently, they were universally exiled from their homeland and found themselves in extreme living conditions in an alien ethnic environment. Chechen and Ingush representatives of the Soviet political-administrative, military and intellectual elites were torn out of the communist establishment and began, in the heart of their people, to try and get a niche in the informal leadership of the traditional clans and religious 'aksakals' and to integrate with them. In the conditions of exile, the Chechen and Ingush traditional clan structures failed to weaken, and gained an even greater definition and a significant source of functional stability. Parallel with this, the general national self-awareness of their peoples grew stronger.

Returning to the homeland after the amnesty in 1957, the Chechens and Ingush found a completely occupied socio-political space and they had to fight it and first of all the Russians little by little. The region where they lived and where their Republic was restored, at that time, thanks to Groznyi oil, became in industrial terms the most developed in the North Caucasus. Chechens and Ingush started once again to create a political-administrative elite and intelligentsia, and to obtain for themselves an increase in political weight in their Republic. But nevertheless, right up until the fall of the communist regime, the ethnic Russian component continued to dominate in political and civil institutions of the Chechnya-Ingushetia Republic. The transformation of the regime, as we have already shown, continued there, by contrast to Dagestan, primarily in the general national movement for liberation from Russian guardianship.

However, it seems strange that nationalism, for all its importance in the social consciousness of Dagestani peoples and Chechens has, in both places, its own peculiar limits of diffusion. In Dagestan, we see that leaders of one and the same nationality bitterly clash among themselves, and often ally with groups of other nationalities. In Chechnya we see equally bitter struggles between authoritative leaders, the grounds for which serve personal ambitions and mercantile motivation and prevail over general national state interests. Why is this so? 


\section{Stability in Dagestan but not in Chechnya?}

In Dagestan, political practice bears witness to the fact that although people do not stop talking about nationalities they have, as a rule, become of secondary importance or have completely lost their importance when it comes to the solution of serious problems. For example, popular leaders of national movements, whose mass authority is based on the clear expression of historical and contemporary grievances, and the needs and demands of their respective nationality, do not succeed in even gathering the necessary number of signatures for registration as a candidate for the republican parliament. If some of them do manage to break through to the ruling class, then it is probably at the price of defending the interests of their respective peoples and owing to other qualities, unrelated to nationality issues. Alternatively, for example, the leader of one nationality 'unexpectedly' forms a political alliance with an authoritative figure of another nationality against a second leader of his or her own nationality.

In Chechnya the overthrow of Doku Zavgaev happened exclusively with support from the centre, in as much as the influential 'Moscow Chechens', for their own personal aims, supported the growing internal opposition of the 'new' Chechens. Subsequently, the fragility of Chechnya's political structure remained the same: a universal change in the ruling class with Dzhakhar Dudaev, and the formation of a new irreconcilable opposition of all who were now out of power.

With all of the pro-Chechen political action and nationalist rhetoric of Dudaev, his power not only failed to strengthen, but actually lessened from the beginning of his leadership. Only the crude and foolish interference from Moscow turned Dudaev into an all-nation leader. On 7 November 1991, Yeltsin with his presidential decree No. 178 'introduced' a state of emergency in Chechnya, on the evening of 8 November Chechnya found out about it, on 9 November the triumphal inauguration of President Dudaev took place and on 10 November 1991 Yeltsin cancelled his ridiculous decree. The threat of a new deportation of Chechens and the crude interference from without rallied the Chechen nation around their new leader. Henceforth Dudaev again gradually began to lose the authority of a national leader and met with growing opposition up until the moment when Russia attacked the mutinous Republic. The war from 1994 to 1996 once again made the Chechens into a monolithic nation fighting an external enemy, but after the end of the war and the gaining of de facto independence, Maskhadov, the victor in the war and in all-nation alternative democratic presidential elections, did not manage to establish effective control over the situation in the country. The leaders of the Chechen people in their narrow mercenary struggle among themselves gave up themselves and the Chechen's national interests, and in the end, on the eve of civil war, and in order to avoid it they found a new supply of national unity in an external enemy: they attacked the neighbouring Republic-Dagestan.

Something is clearly hiding behind the nationalist discourse both in Dagestan and Chechnya. A deepened analysis of the practice of confrontation in 
the top political leadership of Dagestan, studying the mechanisms of appointment to high office, the formation of political groups, research into the electoral behaviour of the population and the adoption of campaigning technologies and much else allows one to draw the conclusion that the nationalist discourse, which dictates to the public conscience the forms and means of thinking about what is happening, does not reveal but hides the genuine structure of political relations which have formed here. In Dagestan the situation usually pictured is such that in the concrete political process in the republic the respective nationalities assume the role of agents of the opposition. However the real subjects in the Dagestani political scene turn out to be structures, which are not present in political discourse and which thus seemingly do not exist in reality. However, they can be uncovered if one turns one's attention from what is happening at the front of the stage to follow concrete internal political events.

These latent organised structures can be provisionally named 'ethnoparties', in as much as they possess all the formal attributes of western European parties:

- a degree of common thinking and corporate interest indispensable for the mobilisation of social forces;

- an organisational structure, consisting of one or several authoritative leaders and a sufficient number of activists to carry out the necessary activities;

- financial support from representatives of the highest property elite and the mass support of certain segments of the population.

The difference is 'merely' in the fact that the leaders of these 'parties', the mass and financial support of their activity, as a rule, are realised by the representatives from one subnational ethnic community at the level of rural villages or groups of closely situated villages, historically linked with each other, i.e. that which in Dagestan has long born the name 'Dzhamaat'. ${ }^{4}$ Among the functionaries of the ethno-parties one can even meet persons of other nationalities, however the key components of these political formations (leaders, financial and mass support) are composed of persons of a single traditional community, more organised than the national groups. Thereby not one Dagestani nationality has a single political centre, i.e. one ethno-party. They serve the interests of particular groups and thus cannot embrace the whole nationality. The leaders of these 'parties' often not only do not unite with other groupings of the same nationality, but even ally themselves with the ethno-parties of representatives of other nationalities against 'their own people', if it seems necessary to them.

What has been said here can be illustrated by the results of election campaigns. The opinion that Dagestanis vote for the representatives of their own nationality and the ruling elite consolidates along ethnic lines is axiomatic in the public consciousness of the Republic, but these ideas do not correspond with actual practice, which can be reconstructed from concrete sources. 
For example, at the election to the Duma in 1996 in the Makhachkalinskii constituency (comprising all of northern and central lowland Dagestan), four authoritative Avar leaders hindered each other in winning the elections and a representative of the relatively sparse Lak nationality, Nadir Khachilaev, became deputy with only 27 per cent of the votes. The Lak population in this constituency comprises not more than 8 per cent of the population.

The election campaign and the elections of the mayor of the Republic's capital, Makhachkala, equally vividly conforms to the thesis that the genuine subjects of the political process are not the nationalities, however much this might seem obvious in everyday perception, but rather concrete 'parties', the basis of which form a denser traditionalist community, acting in a complex system of political relations with other similar structures. In this case the basic struggle developed between the Dargin Said Amirov and the Avar Sheruchan Gadzhimuradov. In the capital of Dagestan the Avar population is considerable larger than the Dargin, but they do not account for more than 26 per cent of all inhabitants of Makhachkala. For some reason, two candidates of Avar nationality lacking even the slightest chance of victory joined the struggle between the two main pretenders. In the end, Said Amirov won with an overwhelming majority (71 per cent of the votes).

In the by-election for a Duma deputy's mandate in 1997 the Lezgin Magomed-Fazil' Azizov won instead of the Avar Ramazan Abulatipov, appointed by the then Vice-President of the Russian Federation in the Buijnaksii region. In the course of the election campaign the following attracted attention. After the well-known Avar leader Gadzhi Makhachev - a figure who would have undoubtedly gone through - for some reason withdrew his candidacy, the 'Avar Popular Movement' which he headed took the decision to support not the candidacy of the Avar Magomed Aliev, who realistically aimed for victory and was supported by the former deputy for the constituency Abdulatipov, but rather a different Avar, Arkadii Ganiev, whose chances were unanimously rated as nil. The real struggle unfolded between the Avar Aliev and the Lezgin Azizov, and the latter won with an impressive result -54 per cent of the votes. In this region Lezgins constitute only 22 per cent of the total population. Of course, the victor could secure himself the block voting of his fellow Lezgins. Indeed, in the five deeply 'Lezgin' districts of Dagestan (Magaramkentskii, Kasumkentskii, Kurachskoii, Achtynskii and Dokusparinskii) he received around 60,000 votes, and his basic rival Magomed Aliev only 150. All in all, in southern Dagestan, which additionally includes Rutul'skii, Aguk'skii, Hivskii, Tabasaranskii and Derbentskii raions, Azizov got more than 130,000 votes and his main rival only 20,000. We observe the mirror image of this in the basically 'Avar' districts. From ten such districts belonging to the constituency Aliev received only 74,000 votes, but Azizov 'captured' from him 11,000 Avar votes. Thus, in the 'purely' Avar district of Gubetovskii out of 7,000 voters, 4,000 voted for the Lezgin Azizov. Azizov's final 
victory was handed to him by the 'Dargin' districts of the republic. In them, Azizov received 53,000 votes and his main opponent 24,000. Azizov came second to Aliev only in the 'Dargin' district of Kaitagskii $(4,800$ votes to 5,200). In the Lakskii district the share of the vote went Aliev's way $(4,500$ to 2,800$)$.

All these and other examples of real political practice bear witness to the fact that Dagestan has not gone down the road of national segregation and that nationalism here, in the final analysis, did not become the catalyst for political confrontation. Although if one were to follow the social-political discourse of this entire period, everything apparently comes down to the problem of national solidarity, of the 'rights' of nationalities to their share of political power, to 'their' land, etc. Why did nationalism yield in the real political process to a different type of solidaristic relationship, constituting the basis of the structure we refer to as ethno-parties? The explanation must quite clearly be sought in history of Dagestan.

From as far back as the early Middle Ages in Dagestan, clan identity was replaced by a political identity, which did not embrace the whole settlement area of ethnographic collectives with a common origin. In the historical chronicles of that time we do not come across clans, but rather well-defined political formations (Derbetskii emirate, Serir, Khaidak, Zerikhgeran, Shandan, Filan, Zuklan, Karakh, Tabasaran, Gumik, Lagz) (Gadzhiev, Davydov and Shikhsaidov 1996: 234-254).

Subsequently from the fourteenth and fifteenth centuries onwards a complex system of independent, but inter-related political formations with norms of selfgovernment developed - the so-called dzhamaats. The ethno-cultural (tribal) uniformity of large areas, which outside observers detected easily, from antiquity up to the present day, already had no political meaning in Dagestan, at least from the fifteenth or sixteenth century onwards.

The social-legal structure of the dzhamaats were essentially uniform throughout Dagestan, but of course with numerous nuances. The dzhamaat, first and foremost, strictly separated its citizens from all outsiders. Belonging to a dzhamaat constituted the strongest identification for a Dagestani and was supported by written laws. The highest degree of punishment was expulsion from the dzhamaat, which led to the loss of its protection and almost certain death or disaster. Every dzhamaat comprised a few (at least three) clan groups, or 'tukhums'. The tukhum (a large community of blood-ties) did not possess any common property and or an inherited leadership (leader of the family). New settlers could be taken into the tukhum, families could move from one tukhum to another and even broader redistributions of the population of a dzhamaat could take place between tukhums. At the same time, civil arrangement of the internal life of a dzhamaat was such that the energy of natural internal tukhum solidarity between members of one clan group was strictly limited and regulated by written dzhamaat laws (adat). ${ }^{5}$ The membership of a dzhamaat member in a certain family group (tukhum) was constituted 'from above' as an institution which, alongside other 
measures, secured public order. The tukhum, in its essence, was a mechanism (a conductor) with the purpose of effectively transmitting decisions of the authorities to the individual members of the dzhamaat. The entire adult male population of the dzhamaat, excluding temporary settlers, guests and prisoners of war, were equal before the law. Ownership of land and all other property was divided up exclusively into dzhamaat (woods, pastures and hayfields), private (farmed plots and gardens) and vakuf, i.e. the formerly private land, inherited or presented by the mosque of the dzhamaat. The basic social cell of the dzhamaat was the family, usually extended, as occurs quite often up to the present day. There was a wellestablished institution of individual private property, especially land. Property rights regarding land were scrupulously determined by dzhamaat laws and were limited only in cases of the sale or gifting of land to another dzhamaat.

In this way, the dzhamaat was the civil and political unit of the traditional social organisation of the Dagestani population. It possessed distinct territorial boundaries. Its land was protected not only with military resources, but also by legislation regarding the rights to buy and sell land. In essence the dzhamaat was a city-state, a polis. ${ }^{6}$ In a certain sense contemporary Dagestani nationalities, founded in the course of the 'socialist settling of the national question', are a bureaucratic 'reanimation' of ancient clan communities, the basis of whose construction was ethno-cultural similarity, i.e. general ethnic characteristics, which can be easily ascertained by objective examination. The total number and list of nationalities, which in the final analysis were institutionalised in the period of communist rule, were (1) the Avars, (2) the Dargins, (3) the Kumyks, (4) the Lezgins, (5) the Tabasarans, (6) the Rutuls, (7) the Aghuls and (8) the Tsakhurs.

The bureaucratic authority which had established this structure of nationalities, only had to disappear and disorder break out for the structures of the traditional political organisation of the Dagestanis to start to revive.

Judging by all of this, traditional social structures have also been revived and involved in the contemporary political process in Chechnya. And here we turn to the deepest difference between Chechnya and Dagestan, the teip (clan) system of Chechen society.

Dagestan, beginning in the fourteenth and fifteenth centuries with the formation period of the main, unified, numerous clan groups (tukhums) and settlements (dzhamaats), went down the path of forming compact territorial political identities of a civic type. Clearly, this depended on the stormy and all-enveloping development of Islam in the region at the same time. Islam at that time in Dagestan was turning into the most important component of the ideological, legal-political and cultural life of every single dzhamaat and, at the same time, was the basic formation of the whole system of internal Dagestani economic, political and cultural relations: the process of dzhamaat union formation, their upper unions, the unified common market system, single language and ideology. In this century (fifteenth-sixteenth) the understanding of 'Dagestan' as a separate and 
distinct political-cultural entity took shape, different to Christian Georgia, Shiite Azerbaijan and heathen Chechnya.

In Dagestan the laid-down structure of a traditional society consisted of the following elements: the family (nuclear or extended); the tukhum (the clan society of close relatives through the male line, existing exclusively within the framework of a given dzhamaat); the dzhamaat (a politically autonomous and territorial unit, organised with the help of civil laws); the 'voluntary society' or 'principality' (political union of a fixed majority of compactly located dzhamaats, on the principle of either equality or inequality, on the basis of a republican or authoritarian regime); Dagestan (a whole economic-cultural and historical-ethnographic society).

Chechen traditional society was built differently: the family - dyuozal, d'ezal (nuclear or extended); $d z h a$ (the extended family, kin, a few closely related families, living nearby); nieke"ii (clan society, the aggregate of related kin, not dependent on the place of residence); gar (the aggregate of related people with distant but genuine common ancestors); teip, var (the aggregate of related gars); tukuam, tukkhum (the tribe, the aggregate of the identified relations, teips and vars); $k^{\prime \prime} a m$ (the whole people, Chechens) (see Nash Dagestan 1995).

In particular, evidence of the deep differences between Dagestanis and Chechens in the organisation of life is that among Dagestanis it is permissible and even encouraged for cousins to marry, whereas Chechens are still categorically opposed to marriages even within the same teip, i.e. between relatives through the father's line, the unity of which can be traced deep into antiquity, over the distance of ten-fifteen generations; there cannot be marital relations as they are still considered 'brother' and 'sister'.

The structure of traditional Chechen society, built on a 'clan' principal, has inescapably turned out to be highly intricate. Thus there is no one opinion on the quantity of teips and tukkhums; sometimes no difference is made between these two categories and sometimes it is particularly emphasised. Sometimes one also hears that one or another teip or tukkhum is 'impure' or 'not Chechen', etc.

The war with Russia which unified all Chechens could not halt the process of stratification of Chechen society into 'teips' ${ }^{7}$ The structures of military units (the army) headed by 'field commanders', to a large extent, reflect the teip structure of contemporary Chechen society.

The coming to power of the first Chechen (Doku Zavgaev) in 1991 switched on a mechanism for internal power struggles in the Republic. With the collapse in the legal and ideological system of the communist regime and open power struggle, the Chechen traditional clan identity should have inescapably become the most important resource for the regulation of social relations. If in Dagestan ethno-parties were built on the foundations of traditional dzhamaat identity, then it is clear that Chechen ethno-parties stand on teip solidarity. However, the difference is that dzhamaat is a distinct fragment of a given nationality - that is, 


\section{Stability in Dagestan but not in Chechnya?}

that social category which is openly controlled and regulated in the system of political relations in Dagestan. As far as teip structure is concerned, it does not exist existentially (it is present in the consciousness of Chechens) so it is not possible to imagine how it could be taken into account.

\section{The Dagestani model of 'consociational democracy'}

The new Constitution of the Republic of Dagestan was passed on 26 July 1994, after three years of tortuous searching for the political structure most acceptable to the republic. For the entire duration of its preparation the key idea of all concepts, which determined the direction of the search and fuelled the basic conflicts and disagreements, was the observation of the 'rights of nationality'. A broad class of social and political activists and specialists - members of the "Group for the Composition of a New Constitution', grappled with a solution to the problems of organising power in the republic, which could offer guarantees for the rights of all the peoples of Dagestan to 'their' respective land and 'their' natural resources, and secure a just representation of every nationality in the organs of state power and in organisations responsible for material production, education, science and culture. However it was impossible, for very understandable reasons, to find public agreement in the solution of such questions.

On the other hand, the highest political leaders, who were to decide what the Constitution of the Republic of Dagestan would look like, were interested in an organisation of power, which would exclude the possibility of its concentration in the hands of one person. All these efforts led in the end to a quite original political structure in Dagestan.

Thus, according to the new Dagestani Constitution, the organ of the supreme executive power consists of fourteen people. These are the members of the State Council, and they are not elected directly by the people, but by a special institution, the Constitutional Assembly, which assembles exclusively for such cases and also for constitutional amendments. It comprises members of the Parliament and also a number of members specially elected by representative assemblies of district and city organs of self-government.

According to the Constitution of Dagestan, 'not more than one representative of a single nationality' can be a member of the State Council, consisting of fourteen members (Article 88). ${ }^{8}$ Members of the State Council cannot be parliamentary deputies, members of the government or judges, but are allowed to combine executive functions with work as procurators, lecturers, managers or employees of corporations or state organisations or enterprises.

Initially the chairman of the State Council - the 'head of state' according to the Dagestan Constitution (Article 92) - is elected secretly by the Constitutional Assembly. A second member of the State Council takes his seat without being elected - this is the Prime Minister, who takes up his post at the suggestion of the 
Chair of the State Council and after confirmation by Parliament. The Prime Minister, in this way, automatically becomes a member of the State Council and, what is more, the first deputy of its Chair. Subsequently, when the nationality of the two aforementioned members of the State Council is known, the procedure of electing the remaining twelve members begins in the Constitutional Assembly. Every member of the Constitutional Assembly independent of his own nationality has the right to recommend a candidacy for the State Council of any nationality for the remaining twelve seats. After the lists of forwarded candidates (who do not necessarily have to be members of the Constitutional Assembly) are drawn up, grouped by nationality, a first secret vote picks out two candidates from each nationality, chosen according to the largest number of votes received. A secret vote then determines which of these two remaining candidates per nationality become members of the State Council.

The Parliament of the Republic (The People's Assembly of the Republic of Dagestan) consists of 121 deputies, elected by universal, direct and confidential ballot in territorial constituencies. At the same time, the Constitution of the Republic of Dagestan ordains that the representation in Parliament of all nationalities of Dagestan be guaranteed' (Article 72), and the mechanism for the realisation of this constitutional norm is secured by the law 'On Elections to the People's Assembly of the Republic of Dagestan'.

According to this law the mechanism for securing national proportionality consists of the following: the territory of the republic is subdivided into ethnically uniform territories (mainly the mountainous regions of Dagestan, which are populated by compact masses of Avars, Dargins, Lezgins. Laks, Tabarasans and other nationalities) and ethnically mixed territories, the cities of the Republic and the rural districts of the plain. In ethnically uniform regions there are no restrictions on the nationality of parliamentary candidates. In the ethnically mixed regions and the cities the Law 'On Elections' gives the Republican Electoral Committee the right to establish special 'national territorial constituencies', in which only candidates from one nationality can campaign. At the same time, the electorate of these multi-ethnic constituencies are in no way subdivided according to nationality; the entire population of the constituency votes for candidates belonging to a single nationality. This is done so that the electoral campaign between authoritative leaders does not go outside of one nationality, and so that for the multi-ethnic electorate of such a constituency the nationality of the candidates is meaningless and has no bearing on the results of the election.

Thus, in the first election in 1995, of the 121 constituencies, sixty-six were nationally defined, i.e. each of them was designated to a certain nationality taking into account the necessary proportion of national representation. ${ }^{9}$ For this purpose twelve Avar, twelve Kumyk, ten Russian, seven Dargin, five Tabasaran, five Azeri, four Lezgin, four Chechen, three Lak, two Tat constituencies and one Tsakhur constituency were created from the multi-ethnic districts and all cities. 
One other constituency was allowed to have candidates of any nationality. This made it possible to avoid the problem of legislative discrimination of members of nationalities apart from the fourteen (for example Armenians, Jews, Georgians, Ukrainians, etc.). These quotas, combined with elections in constituencies with ethnically uniform populations (of which fifty-five remained) made it possible in the end to obtain a parliamentary body which adequately reflected the national composition of the republic's population. The parliamentary election of 1999 took place according to an analogous arrangement.

This entire system succeeds in functioning within the norms of the Constitution of the Republic of Dagestan: 'Everyone has a right to freely choose and indicate his national belonging. No one should be forced to choose and indicate his national belonging' (Article 31).

Apart from the rules regulating the national composition of supreme state institutions, there is also a norm securing the protection of the most important attributes of nationality. Article 81, part 33 of the Constitution of the Republic of Dagestan ordains something resembling the power of veto: 'In the consideration of questions regarding changes in the established administrative-territorial structure and also the demographic, linguistic, socio-economic and cultural environment of the people of Dagestan, in the case of disagreement with the drafted motion of a deputy or a group of deputies from a given territory a decision must be passed with a two-thirds majority in the National Assembly.'

Such a system of taking into account national representation is exposed to constant criticism from the numerically few, but active liberal intelligentsia. The basic flaw is seen to lie in the fact that this system contradicts the rights of a citizen to vote in the constituency in which he wishes to vote. The 'medieval restrictions', in their opinion, establish the regulation of people by national characteristics, which cannot correspond with the norms of the equality of citizens.

Many rules regulating the national balance, although not supported in articles of the Constitution, in laws or in any written rules at all, are strictly carried out in practice. Thus, according to an unwritten rule, the senior figures in the supreme institutions of authority (The Chair of the State Council and of Parliament and of the Prime Minister) have to belong to different nationalities. The Prime Minister's deputies are selected so that representatives of different nationalities are present and, if possible, not more than one belongs to any single nationality. The situation with the deputies of the Chair of the People's Assembly, the leaders of parliamentary committees, the Administration of the State Council, etc. is the same. National representation is also taken into account regarding the senior figures in higher institutions of education and science.

The Dagestani model of political structure was formed free of any influence from the concept of consociational democracy (Lijphardt 1977). At the same time, it is clear that it can be considered to count as such a type of political arrangement. 
The fact that in Dagestan it is not nationalities which oppose each other but ethno-parties signifies a greater pluralism of political forces then it might seem if only nationalities were to be singled out in the Dagestani political structure. That also signifies a more complex intertwining of variegated alliances of political groupings, but at the same time the multiplication of possible causes of confrontation between them. All these circumstances taken together secure political stability in Dagestan and, more importantly, discredit in the public consciousness the nationalist discourse with which representatives of the elites, as a rule, justify their efforts to mobilise 'popular' support for their benefit.

\section{NOTES}

1 In Dagestan live more than thirty ethnic groups. Fourteen are regarded as 'basic' in Dagestan. Traditionally, the political elite is recruited from the four largest groups Avars (28.0 per cent), Dargins (15.8 per cent), Kumyks (13.1 per cent) and Lezgins (11.5 per cent).The overall population is about 1.77 million. (Figures as of 1989 , Natsional'ny sostav naseleniia SSSRpo dannym Vsesoiuznoiperepisi naseleniia 1989 goda (Ethnic Composition of the USSR's Population according to the All-Union Census of 1989), Moscow: Finansy i Statistika, 1991.)

2 Imam Shamil' was a Dagestani Avar from the Gimra dzhamaat. Shamil' was the third leader of the movement (imam) after the Avars Gazimagomed and Gazatbek. The beginning of the opposition to Russia was organised under the leadership of the imams, but opposition also started in 1830 on the territory of Dagestan and not directly against the Russians, but against their stronghold in the mountains - the Khunzakh sovereigns (of the Avar khans). Only after defeat at the hands of tsarist forces in a long and bloody battle on the Akhul'go mountain in 1839 was it necessary for Shamil' to leave and hide in Chechnya, where he got shelter and support. In 1840, when the Chechens yet again rose up in answer to Russian punitive expeditions, Shamil' succeeded in organising their spontaneous demonstrations as a holy war against the unbelievers.

3 Used here in the sense of the Soviet term "nacional'nost", referring to an officially recognised ethno-national group.

4 'Dzhamaat' is an Arabic word, meaning 'society', a distinct organised collective of people. In traditional Dagestan there was no common term, signifying a state formation. They all had their own names (Achty-para, Akusha-dargo, Nutsal' (Chunzach), Utsmiist (Kaitagsk), Antsuch, Agul, etc.). General terms, when they appeared and began to spread, were borrowed from Persian, Arabic or Turkish.

$5 \quad$ Adat' (the Arabic for custom) signifies the usual law of the peoples, which opposes Islamic law - the Shariat. However, the use of this term to refer to the so-called 'Dagestani Adats' is mistaken. The written 'constitution' of the Dagestani political dzhamaat formations ('free societies' and 'unions of free societies') were written and adopted by the mountain people in their time as Muslim Shariah statutes. The perception of them as 'adats' appeared only at the beginning of the nineteenth century amongst Dagestani Myuridist ideologists, who in the course of the war with Russia expanded the struggle with independent dzhamaats for the unification of Dagestan. The demand for the establishing of 'pure Islam' on the whole of Dagestan's territory unavoidably converted the 'constitution' of independent dzhamaats into 'adats', with which to confront the Shariat. The Russian colonial administration and historiography accepted this 'Myuridist' conceptual framework, but in the struggle with this terrible ideological force in Dagestan, they relied on the return of the 'adat'. 


\section{Stability in Dagestan but not in Chechnya?}

6 City-state' and 'polis' are used here although these terms are not used by historians writing about the political history of Dagestan. The generally accepted terms for the political formations of traditional Dagestan outlined here are now 'rural society' or 'feudal society'. Shikhsaidov calls the process of development of political formations of the dzhamaat type in Dagestan in the thirteenth and fourteenth centuries a 'process of development of large villages', 'a period of intensive formation of large settlements', 'the formation of new administrative-territorial units (large settlements)'; Shikhsaidov writes: 'These processes [the growth of villages] also coincided with a time of noticeable strengthening of old and the emergence of new unions of rural communes, with changes in the social structure of Dagestani society' (see Gadzhiev, Davydov and Shikhsaidov 1996: 318-319). The historical phenomenon of the Dagestani 'polis' is so original that until now no term has been found to describe it. Mamaichan Aglarov (1988), who has reflected more than anyone on the phenomenon of Dagestani traditional 'society', writes that Russian soldiers, officials, travellers and historians discovered the principal difference between Dagestani 'societies' and traditional peasant communes. Thus, I. Gerber, one of the best-informed authors, called them 'territorium', similar to the feudal regions of Dagestan, and I. A. Gil'denshtedt (at the end of eighteenth century) termed them 'districts', thus terminologically not differentiating them from political formations, governed by personal rulers. P. G. Butkov (at the end of the eighteenth century) writes about the "the unions of private regions' similar to fiefdoms. A. I. Achverdov, a young officer at the end of the eighteenth century was the first to call them 'republics', after which this term becomes dominant in military and business correspondence in Russian. Thus, the Commander-in-Chief in the Caucasus General-Major Graf Pauluchin in reports to the armed forces minister Rumyantsev in 1812 calls the unions of dzhamaats 'the republican societies of the Lezgin'. S.M. Bronevskii (at the beginning of the nineteenth century) writes of the 'federative republics' in Dagestan. Thereby all these terms are applied exclusively to Dagestan, and not at all to the regions, populated by the mountain peoples of the northern Caucasus. Only with the beginning of the national-liberation war in Dagestan did the 'republics' in Russian business texts change into 'fiefdoms'. This last term stays generally accepted up to the present day (see Aglarov 1988: 6-11). Much new and interesting material regarding the dzhamaat political construction in Dagestan can also be found in Aglarov (1998).

7 In this case we are using the term 'teip' as a generalised category of clan identity of any level significant for Chechens.

8 Fourteen nationalities are regarded as 'basic' in Dagestan (in order of size): Avars, Dargins, Kumyks, Lezgins, Russians, Laks, Tabasarans, Azeris, Chechens, Nogays, Rutuls, Aghuls, Tsakhurs and Tats. It should be emphasised that this list is not fixed in any legislative acts. However there are indirect, but weighty indications to treat them as the "stateforming' nationalities of Dagestan. Two constitutional conditions, i.e. 'the fourteen members of the State Council' and 'one from each people' necessarily point to this choice of nationalities. As we have seen, Russians, Chechens and Azeris are included among the 'Dagestani nationalities'. The fact that these nationalities have a historically rooted rural population on the territory of Dagestan can serve as another indicator of the choice of this number of and of these nationalities.

9 The constitution of Dagestan does not provide for the election of deputies by party lists. All 121 members of parliament are elected by a majority system in single-mandate constituencies. 


\section{REFERENCES}

Aglarov, M. A. (1988), Sel'skaya Obshchina v Narodnom Dagestane v XVII-XIX v. (Moscow). Aglarov, M. A. (1998), Etnogenez v svete politantropolgii i etnomii v Dagestane. Politicaethnica (Mahachkala).

Aliev, B. G. (1999), Soyuzy sel'skikh obshchin Dagestana v XVIII-pervoi polovine XIX v. (Mahachkala).

Dogan, M. and D. Pelassi (1994), Sravnitel'naya politicheskaya sotsiologiya (Moscow).

Gadzhiev, M. G., O. M. Davydov and A. R. Shikhsaidov (1996), Istoria Dagestana s Drevneishikh vremen do kontsa XV veka (Mahachkala).

Gakaev, D. (1999), 'Chechnya i Rossiya: obshchestva i gosudarstva', in D. Gakaev, Put' k chechenskoi revolyutsii (Moscow).

Jaspers, K. (1991), 'Istoki istorii i ee tsel', in Smysl i naznachenie istorii (Moscow).

Lijphart, A. Democracy in Plural Societies (New Haven).

Materialy Vsesoyuznoi perepisi naseleniya 1926 goda po Dagestanskoi ASSR (1927), vyp. 1. Spisok naselennych mest Dagestanskoi ASSR (Mahachkala).

Muzaev, T. and Z. Todua (1992), Novaya Checheno-Ingushetiya (Moscow).

Nash Dagestan (1995), 'Chechnya ot Mansura do Dzhokhara', Nash Dagestan, No. 174-175 (Special Edition).

Takhir al-Karakhi, M. (1941), Chronika Muchammeda tachira al-Karachi o dagestanckich vojnach v period Shamilya, trans. A. M. Barabanova (Moscow and Leningrad). 